Jurnal Sistem Informasi (Journal of Information Systems). 2/10 (2014), 75-82

DOI: http://dx.doi.org/10.21609/jsi.v10i2.389

\title{
EVALUASI PENERIMAAN JEJARING SOSIAL GOOGLE+ PADA SISWA SEKOLAH MENENGAH ATAS DI WILAYAH JAKARTA SELATAN
}

\section{Abdul Mufti, Fitriana Destiawati, dan Tri Yani Akhirina}

Fakultas Teknik Matematika dan Ilmu Pengetahuan Alam, Universitas Indraprasta PGRI, Jl. Nangka No. 58 C, Tanjung Barat, Jakarta Selatan

E-mail: abdul@unindra.net

\begin{abstract}
Based on some research results, first-year high school students in Jakarta is ready to accept Google+ social network technology but not for continuous usage. Therefore, there is a need for a more elaborated research, i.e. using the Unified Theory of Acceptance and Use of Technology (UTAUT) model. This study is conducted to evaluate the acceptance of Google+ that has been done in the first phase of the study. Based on the results of the first phase, Google + is still less acceptable as a learning medium for high school students. The current study is expected to be able to implement Google+ as a social network that can be used to accomplish more tasks. The analysis technique of Structural Equation Model (SEM) is used for data processing. According to the results of this study, it can be concluded that the use of Google technology among high school students, for both girls and boys, is strongly influenced by the condition of supporting facilities. If the environmental conditions and conditions of supporting facilities is good, the interest of high school students to use technology Google+ will be greater.
\end{abstract}

Keywords: Google+, UTAUT, SEM

\begin{abstract}
Abstrak
Berdasarkan hasil penelitian, pada tahun pertama, siswa Sekolah Menengah Atas (SMA) di DKI Jakarta sudah siap menerima teknologi jejaring sosial Google+. Akan tetapi, tidak sampai pada penggunaan secara terus menerus. Oleh sebab itu, perlu adanya pengembangan penelitian yaitu dengan menggunakan model Unified Theory of Acceptance and Use of Technology (UTAUT). Penelitian ini dilakukan untuk mengevaluasi mengenai penerimaan jejaring sosial Google + yang telah dilakukan pada penelitian tahap pertama. Berdasarkan hasil penelitian tahap pertama, jejaring sosial Google + masih dirasa kurang bisa diterima sebagai media pembelajaran siswa SMA. Penelitian kali ini diharapkan mampu menerapkan Google + sebagai jejaring sosial yang dapat digunakan untuk menyelesaikan lebih banyak tugas. Metode pengolahan data yang digunakan adalah teknik analisis Structural Equation Model (SEM). Dari hasil dari penelitian ini, dapat disimpulkan bahwa penggunaan teknologi Google+ di kalangan siswa SMA, baik siswa perempuan maupun laki-laki, sangat dipengaruhi oleh kondisi fasilitas pendukungnya. Jika kondisi lingkungan dan fasilitas pendukungnya baik, maka minat siswa SMA untuk menggunakan teknologi Google+ akan semakin besar.
\end{abstract}

Kata Kunci: Google+, UTAUT, SEM

\section{Pendahuluan}

Berdasarkan hasil penelitian, pada tahun pertama, siswa Sekolah Menengah Atas (SMA) di DKI Jakarta sudah siap menerima teknologi jejaring sosial Google+. Akan tetapi, tidak sampai pada penggunaan secara terus menerus. Alasan mengapa siswa tidak sampai pada penggunaan terus menerus seperti jejaring sosial lainnya dimungkinkan karena kurang popularnya jejaring sosial Google + , kurang menariknya tampilan layer, ataupun cenderung sulit dipelajari. Selain itu, walaupun siswa mengetahui adanya jejaring sosial Google+ ini, siswa cenderung menggunakannya hanya karena keingintahuan yang besar terhadap perkembangan teknolo- gi. Oleh sebab itu perlu adanya pengembangan penelitian yaitu dengan melakukan penambahan variabel atau faktor eksternal seperti lingkungan, kehidupan sosial, dan lainnya. Dengan adanya model ini, para tenaga pengajar dapat memberikan motivasi belajar kepada siswa-siswanya, bahwa adanya teknologi dapat membantu kegiatan belajar-mengajar mereka. Siswa diharapkan dapat membedakan produk-produk teknologi berdasarkan fungsi dan manfaatnya dalam menunjang kegiatan pembelajaran dan penyelesaian tugas siswa.

Penelitian ini dilakukan untuk mengevaluasi mengenai penerimaan jejaring sosial Google+ yang telah dilakukan pada penelitian tahap pertama. Berdasarkan hasil penelitian tahap pertama, jeja- 


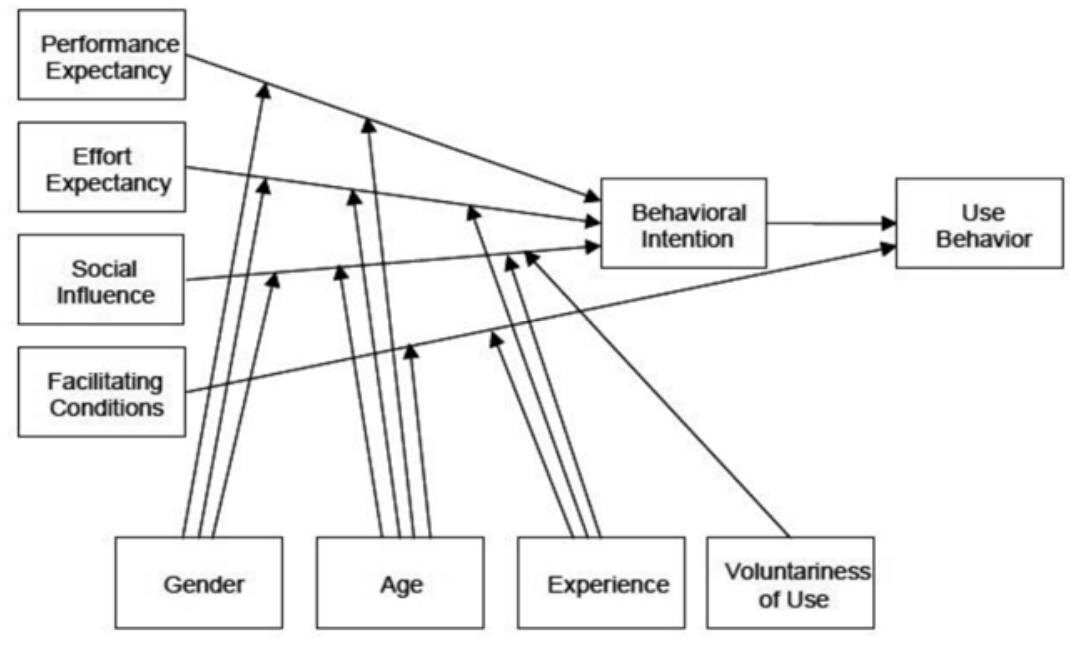

Gambar 1 Model UTAUT

ring sosial Google+ masih dirasa kurang bisa diterima sebagai media pembelajaran siswa Sekolah Menengah Atas. Penelitian kali ini diharapkan mampu menerapkan Google+ sebagai jejaring sosial yang dapat digunakan untuk menyelesaikan tugas lebih mudah dengan kolaborasi Google Apps (Gmail, Google Docs, Google Translate, Google Calender, dll).

Penggunaan jejaring sosial Google+ di lingkungan Sekolah Menengah Atas belum memberikan kontribusi yang cukup besar. Hal ini menjadi kendala dalam penerimaan Google + sehingga dibutuhkan kajian identifikasi, analisis, dan evaluasi tentang sejauh mana penerimaan jejaring sosial Google+ di Sekolah Mengenah Atas. Berdasarkan hal tersebut, dalam penelitian ini dirumuskan apakah faktor-faktor yang saling berhubungan dan berpengaruh terhadap tingkat penerimaan tekno-logi khususnya teknologi jejaring sosial Google + di Sekolah Menengah Atas. Dengan demikian, hasil penelitian dapat digunakan sebagai landasan dalam membuat bahan ajar yang memberikan kemudahan bagi siswa dalam mempelajari penggunaan jejaring sosial Google + dengan berbagai keunggulanannya dibanding jejaring sosial yang umum digunakan, sehingga menimbulkan minat untuk digunakan sebagai media untuk membantu proses belajar siswa.

\section{Model Unified Theory of Acceptance and Use of Technology}

Model Unified Theory of Acceptance and Use of Technology (UTAUT) seperti yang terlihat pada Gambar 1 merupakan salah satu model penerimaan teknologi yang dikembangkan oleh [1]. Model ini disusun berdasarkan model-model penerimaan teknologi sebelumnya seperti Theory of Reasoned
Action (TRA) [2], Theory of Planned Behavior [3], Task-Technology Fit Theory [4], terutama Technology Acceptance Model (TAM) [5]. UTAUT terbukti lebih berhasil dibandingkan kedelapan teori yang lain dalam implementasi pada 70 persen varian pengguna [6-8].

Terdapat empat faktor yang memunculkan user acceptance dari model UTAUT ini, yaitu: 1) Performance expectancy, yaitu tingkatan keyakinan pengguna bahwa dengan menggunakan suatu sistem akan membantu pengguna menghasilkan performansi kerja yang maksimal. Teori-teori yang tergabung dalam performance expectancy adalah perceived usefulness, extrinsic motivation, job-fit, relative advantage, dan outcome expectations; 2) Effort expectancy, yaitu tingkatan kemudahan yang dirasakan pengguna dalam menggunakan suatu sistem. Teori-teori yang tergabung dalam effort expectancy adalah perceived ease of use, complexity, dan ease of use; 3) Social influence, yaitu kesadaran seseorang mengenai adanya orang lain yang menggunakan sistem. Teori-teori yang tergabung dalam social influence adalah subjective, social factor, dan image; 4) Facilitating conditions, yaitu keyakinan adanya fasilitas organisasi dan teknis yang mendukung aktivitas pengguna. Teori-teori yang tergabung dalam facilitating conditions adalah perceived behavioral control, facilitating conditions, dan compatibility.

Performance expectancy, effort expectancy, social influence dan facilitating conditions berhubungan dengan intention behavior yang akhirnya menghasilkan behavior use. Behavior use menjadi pengukuran user acceptance dari sebuah sistem.

Di samping itu, terdapat pula empat moderator kunci untuk model UTAUT ini, yaitu: gender, age, experience dan voluntary. Venkatesh, et al. 


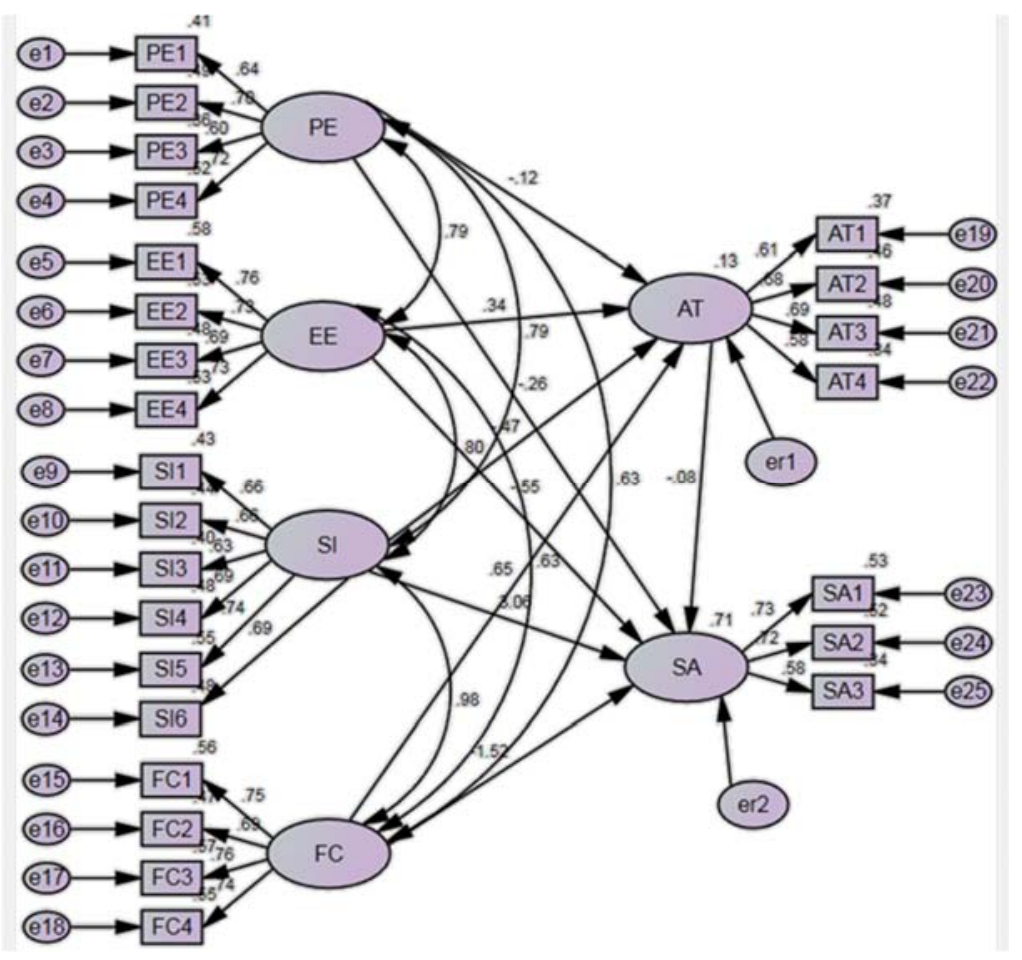

Gambar 2. Model Awal Penelitian

mengemukakan UTAUT merupakan model yang disusun berdasarkan teori-teori dasar mengenai perilaku penggunaan teknologi dan model penerimaan teknologi yaitu TRA, TAM, TPB, motivational model, model pemanfaatan personal computer, teori difusi inovasi, dan SCT [1].

\section{Google+}

Google plus merupakan salah satu produk dari Google Inc. Google+ merupakan produk jejaring sosial buatan Google yang diluncurkan pada tanggal 28 Juni 2011. Sebagai jejaring sosial, Google+ memiliki fungsi yang hampir sama dengan jejaring sosial yang telah populer sebelumnya, seperti Facebook. Google+ mengintegrasikan layanan sosial seperti Google Profile dan Google Buzz serta beberapa layanan baru yaitu Circle, Hangouts, Sparks, Streams, Instant Upload dan Messenger.

Di antara kelebihan atau keunggulan dari aplikasi Google+ adalah adanya fasilitas untuk repost yang diberi nama dengan reshared. Fasilitas ini mirip dengan fasilitas retweet yang ada pada jejaring sosial Twitter. Jadi pengguna bisa langsung mengutip status teman yang terhubung dengan circle. Pada jejaring sosial Google+ pengguna juga dapat melakukan pengaturan status. Dengan demikian, pengguna dapat mengatur apakah statusnya bisa atau tidak di-share kembali dan dikomentari.
Kelebihan lain dari Google+ adalah terdapat fasilitas hangouts yang memungkinkan pengguna untuk melakukan video chat dengan temannya. Google+ juga memiliki mode huruf yang cukup beragam. Pada jejaring sosial Google+ pengguna dapat mengatur tulisan menjadi tebal, miring, maupun coret. Di Google+ pengguna dapat membuat tag dengan menggunakan '@' dan ‘+', bahkan dengan menggunakan versi mobile. Hal ini sama seperti fitur yang dimiliki Facebook.

Fasilitas Huddle seperti halnya fasilitas chat group yang ada pada Yahoo Messenger juga dapat ditemukan pada Google+. Pengguna juga dapat mengunggah atau mengunduh gambar dengan format GIF meskipun membuat loading time menjadi lama.

Google + memiliki fasilitas dimana pengguna dapat melihat langsung status yang dikomentari sekaligus bisa langsung membalasnya tanpa harus menuju halamannya. Tidak seperti Facebook, yang untuk melihat komentar dan membalas komentar pengguna harus menuju halaman yang ingin dikomentari.

Google+ memiliki fitur data liberation dimana pengguna dapat membawa data kemanapun ia pergi seperti halnya penggunaan teknologi cloud computing. Selain itu, tampilan profil yang sederhana namun tetap elegan membuat Google+ lebih ringan dan tidak memakan bandwith yang besar. 


\section{Metode}

Populasi pada penelitian ini adalah Siswa SMA di Wilayah Jakarta Selatan. Populasi diambil mulai dari Tingkat I hingga III. Jenis sampel dan unsur populasinya tidak dipilih secara acak. Hal ini dikarenakan teknik pengambilan sampel yang digunakan adalah teknik Purposive Sampling.

Dalam menguji hipotesis peneliti menggunakan metode statistic multivariate yaitu Structural Equation Model (SEM) [9] dengan tujuan untuk memperoleh model yang plausible atau sesuai dengan masalah yang sedang dikaji pada penelitian ini. Selain itu metode analisis menggunakan SEM memiliki tujuan juga untuk mengetahui hubungan kausal antar variable dependent atau independent pada model yang dibangun. Adapun langkah-langkah dari metode analisis dengan menggunakan teknik analisis SEM adalah sebagai berikut:

\section{Pengembangan Model Berbasis Teori}

Tujuan pengembangan model berbasis teori ini adalah untuk mengembangkan sebuah model yang mempunyai pembenaran secara teoritis yang kuat untuk mendukung upaya analisis terhadap suatu masalah yang menjadi objek penelitian.

\section{Uji Validitas dan Reliabilitas}

Uji validitas digunakan untuk menguji keakuratan suatu indikator sehingga dapat mewakili suatu variabel laten. Sedangkan uji reliabilitas merupakan suatu ukuran konsistensi internal dari indikator-indikator suatu variable bentukan yang menunjukan derajat setiap indikator sebagai konstruktor variable bentukan.

\section{Uji Asumsi Model}

Tindakan yang dilakukan adalah mengevaluasi apakah data tersebut telah memenuhi asumsi-asumsi SEM. Asumsi-asumsi yang harus dipenuhi adalah:

- ukuran sampel yang digunakan berkisar antara $100-200$

- $\quad$ normalitas (dengan melihat nilai critical ratio skewness dan critical ratio curtosis value yang berada pada -2.58 sampai 2.58 dengan tingkat signifikasi 0.01 maka data dianggap normal)

- $\quad$ outliers, deteksi terhadap multivariate outlier dilakukan dengan memperhatikan nilai $\mathrm{Ma}-$ halonobis Distance Table. jika nilai p1 dan $\mathrm{p} 2$ $<0.05$ maka data dianggap outlier.

- multikolinearitas dan singularitas, yang dapat dideteksi dari determinan matrik kovarians, jika determinan dari matrik kovarians sangat besar atau jauh dari angka nol maka data tersebut valid.

\section{Uji Kesesuaian Model}

Pengujian ini adalah uji model secara menyeluruh yang ditujukan untuk mengukur kesesuaian antara matriks varian kovarian sampel (data observasi) dengan matrik varian kovarian berdasarkan model yang diajukan. Dengan kata lain, uji ini digunakan untuk menyatakan model apakah fit atau tidak. Jika model dianggap tidak fit maka penelitian selanjutnya harus dilakukan melakukan path diagram. Tujuannya adalah untuk memudahkan dalam melihat hubungan kausalitas yang ingin diuji.

\section{Uji Signifikansi}

Setelah model penelitian menggunakan diagram jalur terbentuk, kemudian dilakukan pengujian signi-

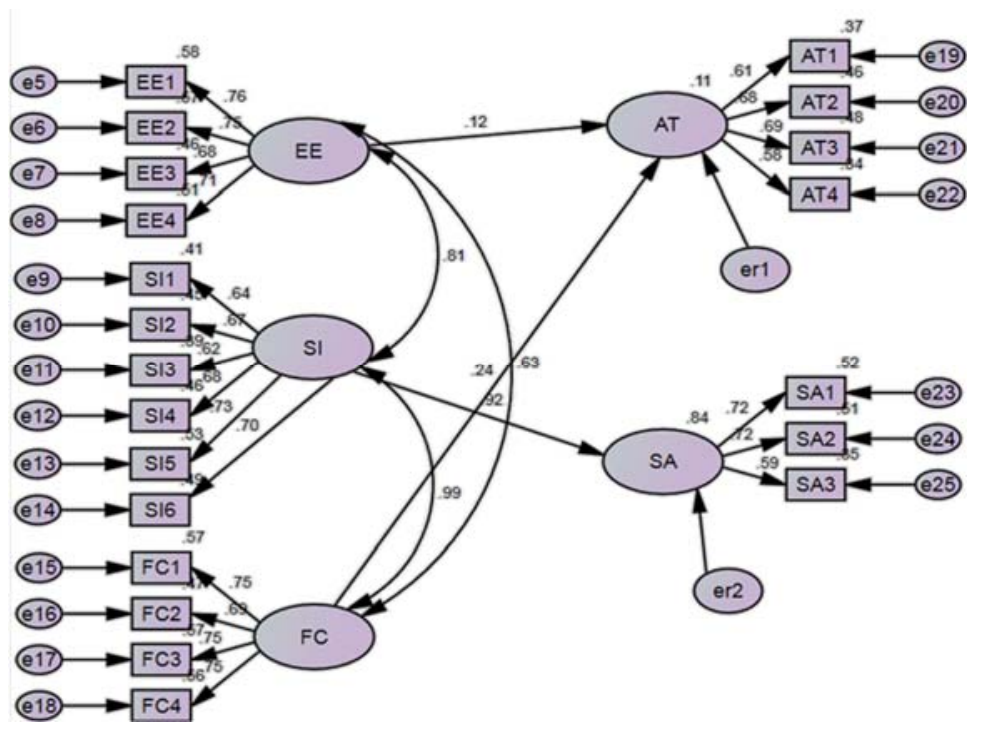

Gambar 3 Model penelitian setelah uji validitas dan reliabilitas 


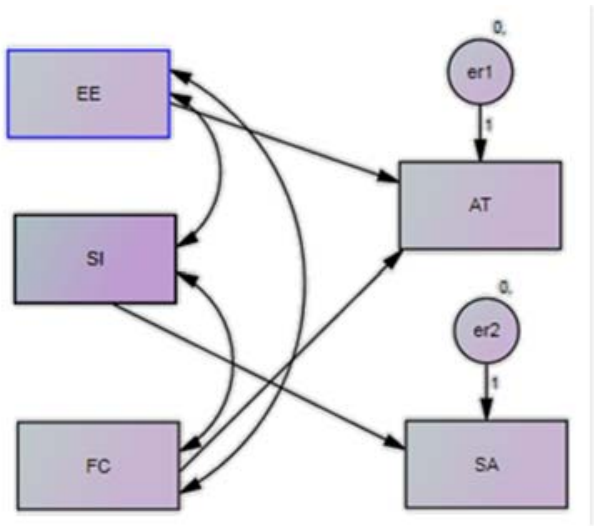

Gambar 4. Model Analisa Jalur

fikasi. Jika terdapat koefisien regresi yang bernilai negatif atau yang tidak signifikan maka dihapus. Suatu nilai $\mathrm{p}$ dianggap signifikan apabila nilai $\mathrm{p}$ tersebut memiliki angka dibawah 0.05 .

Analisis Sub-Group Moderating Model Analisis sub-group moderating model merupakan suatu model analisis dengan memisahkan variabel moderating menjadi dua kelompok. Pemisahan ini umumnya berdasarkan nilai rata-rata, yaitu jika suatu nilai berada di atas rata-rata (tinggi) atau di bawah rata-rata (rendah). Setelah itu, dilakukan estimasi terhadap dua model dengan kondisi variabel moderating tinggi dan rendah. Langkah selanjutnya adalah membandingkan hasil koefisien parameter kedua model untuk melihat ada tidaknya pengaruh moderasi dalam model.

\section{Hasil dan Analisis}

Responden yang ada pada penelitian ini adalah siswa SMA di wilayah Jakarta Selatan dengan jumlah responden sebanyak 240 responden yang diklasifikasi berdasarkan jenis kelamin dan tingkat atau kelas.

\section{Pengujian Model Berbasis Teori}

Pengujian model berbasis teori dilakukan menggunakan aplikasi yaitu AMOS 18 dengan melakukan pengolahan data berdasarkan hasil penginputan data yang didapatkan dari kuisioner. Data yang telah diinput diolah dengan menggunakan model seperti Gambar 2 dengan penjelasan sebagai berikut:

\section{Uji Validitas}

Pada penelitian ini dilakukan analisis model CFA (Confirmatory Factor Analysis). Analisis model CFA dapat dilihat pada Uji Confirmatory Factor
Analysis. Suatu konstruk dapat dikatakan valid apabila nilai estimasi $\geq 0,5$.

Variabel Performance Expectancy (PE), Effo$r t$ Expectancy (EE), Social Influence (SI), Facilitating Conditions (FC), dan Attitude Toward Technology (AT) dinyatakan valid karena semua konstruk yang ada pada variabel tersebut memiliki nilai estimasi diatas 0.5. Sedangkan untuk variabel Symbolic Adoption (SA) dinyatakan tidak valid karena pada variabel tersebut terdapat konstruk yang memiliki nilai dibawah 0.5 .

\section{Uji Reliabilitas}

Pada Tabel 1 terlihat semua konstruk variabel laten PE, EE, SI, FC, AT, dan SA memenuhi syarat cutof value untuk construct reliability (CR) minimal 0.7. Sedangkan nilai variance extracted untuk konstruk variabel laten EE dan FC memenuhi batas nilai variance extracted yaitu berada di atas 0.50. Akan tetapi untuk variabel laten PE, SI, AT, dan SA memiliki nilai variance extracted di bawah 0.5 . Dengan demikian, dapat dikatakan bahwa masingmasing variabel memiliki realibilitas yang baik.

\section{Uji Asumsi}

Uji asumsi dilakukan terhadap model penelitian yang dihasilkan berdasarkan uji validitas dan uji reliabilitas. Jika dilihat secara univariate maupun multivariate, maka nilai CR berada di luar kisaran -2.58 sampai 2.58 (signifikan pada 1\%). Secara multivariate nilai $\mathrm{CR}$ yaitu 4.935 yang nilainya jauh di atas 2.58, sehingga dapat disimpulkan bahwa data berdistribusi tidak normal. Sedangkan untuk uji outlier didapatkan bahwa ada 42 responden yang mengalami outlier sehingga data-data responden tersebut harus dihapuskan dari proses analisis. Dengan demikian, terdapat 198 responden yang tersisa.

Berdasarkan nilai determinan yang tidak sama dengan 0 pada uji singularitas, dapat dianggap bahwa tidak ada masalah multikolinearitas maupun singularitas pada data yang dianalisis.

\section{Uji Kesesuaian Model}

Uji kesesuaian model dilakukan dengan melihat nilai probabilitas. Berdasarkan hasil output dari model penelitian yang ada, maka nilai probabilitasnya adalah 0.000 atau berada di bawah 0.05 . Dengan demikian model penelitian dianggap tidak fit dan harus dilakukan pengujian menggunakan model jalur atau path diagram.

\section{Uji Signifikansi}

Nilai $\mathrm{p}$ untuk AT $\leftarrow$ FC dan $\mathrm{SA} \leftarrow$ SI memiliki nilai lebih kecil dari 0.05 maka dianggap signifikan. Sedangkan AT $\leftarrow$ EE memiliki nilai lebih dari 0.05 maka dianggap tidak signifikan. Oleh karena itu, jalur tersebut harus dihapus. 


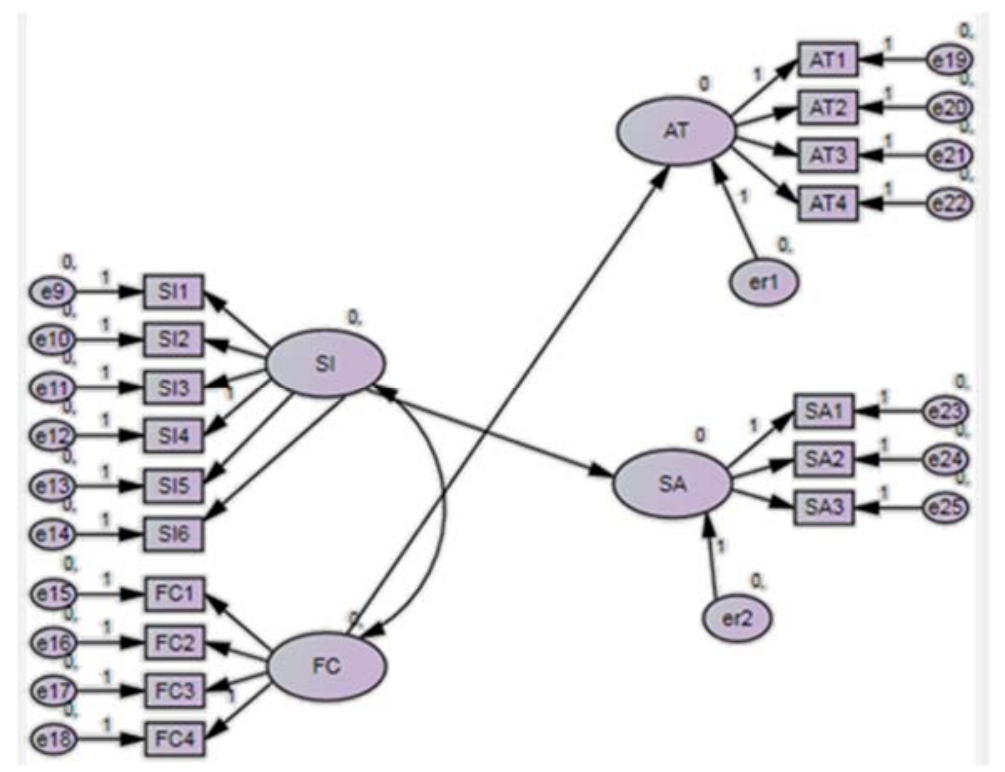

Gambar 5. Model Akhir Penelitian

Analisis Sub-Group Moderating Model

Jika dilihat berdasarkan analisis sub-group moderating model untuk keragaman jenis kelamin, maka pengaruh sosial dan kondisi fasilitas sangat mempengaruhi penerimaan dan penggunaan sistem oleh pengguna laki-laki maupun perempuan baik di kelas X, XI, atau XII.

\section{Model Akhir Penelitian}

Setelah dilakukan uji signifikansi maka terdapat jalur yang dihapus yaitu jalur dari variabel KI menuju KP. Berdasarkan hasil uji signifikan tersebut maka didapatkan model analisis akhir sebagaimana terdapat pada Tabel 1 .

\section{Kesimpulan}

Berdasarkan hasil penelitian yang telah dilakukan maka dapat disimpulkan bahwa hasil model akhir penelitian bahwa variable attitude toward technology (AT) dipengaruhi oleh variabel facilitating conditions (FC). Penggunaan teknologi Google+ di kalangan siswa SMA sangat dipengaruhi oleh kondisi fasilitas pendukungnya. Jika kondisi lingkungan dan fasilitas pendukungnya baik, maka minat siswa SMA untuk menggunakan teknologi Google+ akan semakin besar. Oleh karenanya, apabila pemanfaatan teknologi Google+ sebagai sarana pembelajaran siswa di sekolah ingin diterima dengan baik, seharusnya sekolah tersebut juga didukung dengan fasilitas-fasilitas yang baik. Contoh fasilitas pendukung yang paling penting adalah koneksi Internet yang baik. Koneksi Internet yang baik akan memudahkan siswa dalam menggunakan teknologi Google+ karena, teknologi ini membu- tuhkan koneksi Internet yang cukup banyak dalam penggunaannya.

Berdasarkan model akhir penelitian didapatkan bahwa variabel symbolic adoption (SA) dipengaruhi oleh variabel social influence (SI). Pengaruh sosial dari lingkungan sekitar dapat mempengaruhi penerimaan teknologi Google+ di kalangan siswa SMA. Hal ini berarti bahwa siswa SMA sebenarnya dapat menerima teknologi Google+. Akan tetapi penerimaan mereka terhadap teknologi ini bukan karena kebutuhan dari diri mereka sendiri, melainkan berdasarkan adanya pengaruh dari teman atau orang-orang sekitarnya yang telah menggunakan teknologi ini.

Berdasarkan hasil uji moderasi siswa laki-laki maupun perempuan dari semua tingkatan kelas (X, XI, dan XII), tingkat penggunaan teknologi ini ternyata juga dipengaruhi oleh lingkungan sosial dan kondisi fasilitas pendukung.

Penelitian ini berimplikasi pada 3 (tiga) aspek utama, yakni: aspek manajerial, aspek sistem dan aspek penelitian lanjutan.

Dilihat dari aspek manajerial, pihak sekolah sebaiknya mendukung penggunaan Google+ sebagai salah satu sarana pembelajaran dengan memanfaatkan fasilitas Google Doc dalam berbagi pengolahan data. Pihak sekolah juga memberikan pembelajaran tentang pemanfaatan teknologi media sosial untuk hal yang lebih positif, misalnya, untuk berbagi data dalam mengerjakan tugas, sebagai sarana e-learning, dan sebagainya. Sehingga media sosial bisa dimanfaatkan lebih baik lagi. Sementara dari aspek sistem, pihak sekolah diharapkan dapat meningkatkan kualitas fasilitas pendukung bagi 
TABEL 1

HASIL UjI RELIABELITAS

\begin{tabular}{|c|c|c|c|c|c|c|c|c|c|c|c|c|}
\hline \multirow[t]{2}{*}{ Indikator } & \multicolumn{2}{|c|}{ Konstruk PE } & \multicolumn{2}{|c|}{ Konstruk EE } & \multicolumn{2}{|c|}{ Konstruk SI } & \multicolumn{2}{|c|}{ Konstruk FC } & \multicolumn{2}{|c|}{ Konstruk AT } & \multicolumn{2}{|c|}{ Konstruk SA } \\
\hline & $\begin{array}{l}\text { Fakt } \\
\text { or } \\
\text { Load } \\
\text { ing }\end{array}$ & $\begin{array}{l}\text { Eror } \\
\text { Peng } \\
\text { ukur } \\
\text { an }\end{array}$ & $\begin{array}{l}\text { Fakt } \\
\text { or } \\
\text { Load } \\
\text { ing }\end{array}$ & $\begin{array}{l}\text { Eror } \\
\text { Peng } \\
\text { ukur } \\
\text { an }\end{array}$ & $\begin{array}{l}\text { Fakt } \\
\text { or } \\
\text { Load } \\
\text { ing }\end{array}$ & $\begin{array}{l}\text { Eror } \\
\text { Peng } \\
\text { ukur } \\
\text { an }\end{array}$ & $\begin{array}{l}\text { Fakt } \\
\text { or } \\
\text { Load } \\
\text { ing }\end{array}$ & $\begin{array}{l}\text { Eror } \\
\text { Peng } \\
\text { ukur } \\
\text { an }\end{array}$ & $\begin{array}{l}\text { Fakt } \\
\text { or } \\
\text { Load } \\
\text { ing }\end{array}$ & $\begin{array}{l}\text { Eror } \\
\text { Peng } \\
\text { ukur } \\
\text { an }\end{array}$ & $\begin{array}{l}\text { Fakt } \\
\text { or } \\
\text { Load } \\
\text { ing }\end{array}$ & $\begin{array}{l}\text { Eror } \\
\text { Peng } \\
\text { ukur } \\
\text { an }\end{array}$ \\
\hline PE1 & 0.666 & 0.556 & & & & & & & & & & \\
\hline PE2 & 0.816 & 0.334 & & & & & & & & & & \\
\hline PE3 & 0.560 & 0.686 & & & & & & & & & & \\
\hline PE4 & 0.611 & 0.627 & & & & & & & & & & \\
\hline EE1 & & & 0.722 & 0.479 & & & & & & & & \\
\hline EE2 & & & 0.730 & 0.467 & & & & & & & & \\
\hline EE3 & & & 0.684 & 0.532 & & & & & & & & \\
\hline EE4 & & & 0.776 & 0.398 & & & & & & & & \\
\hline SI1 & & & & & 0.647 & 0.581 & & & & & & \\
\hline SI2 & & & & & 0.666 & 0.556 & & & & & & \\
\hline SI3 & & & & & 0.695 & 0.517 & & & & & & \\
\hline SI4 & & & & & 0.655 & 0.571 & & & & & & \\
\hline SI5 & & & & & 0.784 & 0.385 & & & & & & \\
\hline SI6 & & & & & 0.629 & 0.604 & & & & & & \\
\hline $\mathrm{FC1}$ & & & & & & & 0.808 & 0.347 & & & & \\
\hline $\mathrm{FC} 2$ & & & & & & & 0.655 & 0.571 & & & & \\
\hline FC3 & & & & & & & 0.708 & 0.499 & & & & \\
\hline FC4 & & & & & & & 0.762 & 0.419 & & & & \\
\hline AT1 & & & & & & & & & 0.611 & 0.627 & & \\
\hline AT2 & & & & & & & & & 0.644 & 0.585 & & \\
\hline AT3 & & & & & & & & & 0.731 & 0.466 & & \\
\hline AT4 & & & & & & & & & 0.582 & 0.661 & & \\
\hline SA1 & & & & & & & & & & & 0.613 & 0.624 \\
\hline SA2 & & & & & & & & & & & 0.867 & 0.248 \\
\hline SA3 & & & & & & & & & & & 0.554 & 0.693 \\
\hline SA4 & & & & & & & & & & & & \\
\hline Jml. faktor & 2.653 & & 2.912 & & 4.076 & & 2.933 & & 2.568 & & 2.034 & \\
\hline $\begin{array}{l}\text { Jml. kuadrat } \\
\text { faktor loading }\end{array}$ & 1.796 & & 2.124 & & 2.785 & & 2.164 & & 1.661 & & 1.434 & \\
\hline $\begin{array}{l}\text { Jml. eror } \\
\text { pengukuran }\end{array}$ & & 2.203 & & 1.876 & & 3.214 & & 1.836 & & 2.339 & & 1.565 \\
\hline $\begin{array}{l}\text { Konstruk } \\
\text { reliabel }\end{array}$ & 0.762 & & 0.819 & & 0.838 & & 0.824 & & 0.738 & & 0.725 & \\
\hline Varian & 0.449 & & 0.531 & & 0.464 & & 0.541 & & 0.415 & & 0.478 & \\
\hline
\end{tabular}

siswa seperti koneksi internet, fasilitas laboratorium yang layak dan memadai.

Dari aspek penelitian lanjutan, pada penelitian ini hanya melihat penerimaan dan penggunaan siswa terhadap teknologi Google + . Pada penelitian selanjutnya diharapkan dapat melihat tingkat efektivitas dari teknologi Google+ terhadap media pembelajaran siswa SMA.

\section{Referensi}

[1] Venkatesh, V., Morris, M.G., Davis, G.B. and Davis, F.D., 2003. User acceptance of information technology: Toward a unified view. MIS quarterly, pp.425-478.

[2] Sheppard, B.H., Hartwick, J. and Warshaw, P.R., 1988. The theory of reasoned action: A meta-analysis of past research with recommendations for modifications and future research. Journal of consumer research, 15(3), pp.325-343.
[3] Ajzen, I., 1985. From intentions to actions: A theory of planned behavior. In Action control (pp. 11-39). Springer Berlin Heidelberg.

[4] Goodhue, D.L. and Thompson, R.L., 1995. Task-technology fit and individual performance. MIS quarterly, pp.213-236.

[5] Davis, F.D., 1985. A technology acceptance model for empirically testing new end-user information systems: Theory and results (Doctoral dissertation, Massachusetts Institute of Technology).

[6] Nasir, Muhammad. 2013. Evaluasi Penerimaan Teknologi Informasi Mahasiswa di Palembang Menggunakan Model UTAUT. Seminar Nasional Aplikasi Teknologi Informasi (SNATI). Yogyakarta.

[7] Siahaan, Michael Sonny. 2011. Jurnal: Kajian Unified Theory of Acceptance and Use of Technology Dalam Penggunaan Open Source Software Database Management System: Studi Kasus Universitas Indraprasta PGRI. 
[8] Prasetyo, Basuki Hari, Dian Anubhakti. 2011. Kajian penerimaan Sistem E-Learning dengan Menggunakan Pendekatan UTAUT Studi Kasus Fakultas Teknologi Informasi Univer- sitas Budi Luhur. BIT Vol. 8 No.2 September 2011.

[9] Widodo, Prabowo Pudjo. 2006. Langkahlangkah Dalam SEM Pemodelan Persamaan Struktural, Seri SEM. Jakarta. 